\title{
Modelling and developing a neighbourhood low carbon system for five dwellings in the U.K.
}

\author{
Xiaojun $\mathrm{Li}^{1}$, Shan Shan Hou ${ }^{1}$, Joanne Patterson ${ }^{1}$, Emmanouil Perisoglou ${ }^{1}$, Miltiadis Ionas ${ }^{1}$, Huw \\ Jenkins $^{1}$, Phil Jones ${ }^{1}$, Simon Lannon ${ }^{1}$, Ester Coma Bassas ${ }^{1}$ \\ ${ }^{1}$ Cardiff University, Cardiff, United Kingdom
}

\begin{abstract}
This paper presents a case study of a neighbourhood low carbon energy system designed for five off-gas rural dwellings in the UK. The employment of the neighbourhood system aims to improve energy efficiency of the whole site, reduce dependency on heating oil or LPG for off-gas houses, maximize renewable energy usage on site, and minimize fuel poverty through affordable investments. System design is discussed and built on site survey, on-going monitoring and validated modelling. Simulation is carried out in dynamic model HTB2. A ROI analysis is used to examine the long-term cost-effectiveness, taking into account any maintenance and replacement cost, degradation of system performance and discounting of money over time. The neighbourhood system scenario is compared with an alternative scenario of separate systems for individual houses, in terms of energy reduction, energy self-sufficiency, $\mathrm{CO}_{2}$ reduction and pay-back time. The simulation results indicate the designed optimal neighbourhood system can achieve similar self-sufficiency as that of a separate system scenario, with more than $70 \%$ of its electricity demand met by onsite electricity production. Both the neighbourhood system approach and the separate one can achieve carbon negative for the whole site, with the former contributing to $31 \%$ more carbon reduction than the latter. The neighbourhood system can be paid back within its lifespan, while the separate system approach can't. The payback time of the neighbourhood system can be reduced to 14 years if traditional bolt on PV system is used instead of building integrated PV. The outcome of the research demonstrated the affordability and replicability of the neighbourhood low carbon energy system, which can decrease fuel poverty, and meet government targets for $\mathrm{CO}_{2}$ reduction.
\end{abstract}

\section{Introduction}

Fuel or energy poverty has been a key driver of low carbon domestic retrofit (Welsh government, 2016a). UK's annual fuel poverty statistics report presents an estimation of $11 \%$ (approximately 2.50 million) of all household in England living in fuel poverty, which is an increase of $0.4 \%$ from 2014 (DBEIS, 2017). And BRE's research estimates around 291,000 households, equivalent to $23 \%$ of all households in Wales who still live in fuel poverty, and a higher proportion of social housing tenants were supposed to be fuel poor compared to all households (Welsh government, 2016a). It has been found older dwellings have a higher proportion of households in fuel poverty compared to new dwellings, with a much larger fuel poverty gap in between (DBEIS, 2017). Households off mains gas are likely to be in fuel poverty. In Wales, $46 \%$ of rural homes use heating oil, and $49 \%$ of these off-gas households are in fuel poverty (CAS, 2016). Hence low carbon retrofit is in need for optimizing their existing building fabrics and energy systems, in particular for those off-gas social houses in the rural area, a deep retrofit is needed. However, the initial investment of deep energy retrofit can be pricy, such as between 2010 and 2012 a series of government commissioned deep retrofits costing between $£ 50,000$ to $£ 168,000$ (Baeli, 2013). The payback time is still long, even considering the financial support from the UK government, such as the Feed-In Tariff (FIT) and the Renewable Heat Incentive (RHI). Recent research on integrating existing and emerging low carbon technologies showed a more cost-competitive approach, with a retrofit cost ranging from $£ 23,852$ to $£ 30,510$ for individual houses (Jones et al. 2017). Based on this, the paper discusses the affordability and replicability of a neighbourhood low carbon energy system to supply five off-gas social houses in the UK, with a comparison of system performance and long-term economic performance between the neighbourhood system and a conventional approach of separated systems for individuals.

The proposed energy system employs ground source heat pump, solar PV and battery storage to meet energy demands for space heating, hot water, lighting and electrical appliances. The targeted five 1970s-built Welsh bungalow terraces are located next to each other in a rural area, and they are all off-gas social housing, occupied by single or couple. The employment of the neighbourhood system aims to improve energy efficiency of the whole site, reduce dependency on heating oil or LPG for off-gas houses, maximize renewable energy usage on site, and minimize fuel poverty through affordable investments. Energy demand differences between households have been accounted using measured electricity usage data. A comparison between the neighbourhood system approach and the separate system approach is carried out to examine the affordability and replicability. Building energy simulation is carried out in dynamic thermal model HTB2 (Heat Transfer through Building), combined with its extensions VirVil SketchUp (both software developed by Welsh School of Architecture, Cardiff 
University) and the EDSS model developed by the authors. The building energy model is validated using recent energy bills.

\section{Method}

The development of the neighbourhood system follows four steps, such as pre-retrofit survey and monitoring, preretrofit scenario modelling and validation, modelling and comparing the energy and environmental performance of the neighbourhood system approach and the separate one, long-term economic analysis.

\section{Pre-retrofit energy survey and monitoring}

At the early stage, the authors applied diagnostics tools to be able to detect and quantify fabric defects, occupants' discomfort and areas of improvement. A building survey was carried out including identification of services, dimensional measurements, photography, thermography as well as testing of the thermal resistance and air tightness of the building envelope. Also, semi structured interviews of the occupants identified patterns, needs and practices of the users. Energy performance certificates and billing history were gathered and analysed. After the surveying and one-off testing, a 12-month building performance monitoring was carried to gather environmental and, energy data in order to understand and diagnose long term issues and the inform dynamic modelling. Air permeability was calculated by on-site pressure tests following the TM23 CIBSE guidance (CIBSE, 2000) and using a blower door kit. Wireless temperature and humidity sensors were installed in all living spaces and clamp-on current meters were installed in all five bungalows to measure the electricity demand. Both environmental and energy time interval was synchronised every 5 minutes for a period of twelve months.

\section{Pre-retrofit performance modelling and validation}

The pre-retrofit building performance was modelled and compared with data collected onsite to validate the model. As occupant behaviour is unpredictable, a typical day scenario was developed based on, average hourly electricity usage by lighting and appliance from measurement, hourly occupancy profile and heating profile according to survey, hourly natural ventilation and air infiltration based on survey and pressure tests. The fabric construction details were collected and checked from survey and related EPC reports if available. Heating was set for the UK heating season only, namely from October to April. The early model went through calibrations as more and more information were gathered and checked, and results of the calibrated model are compared with energy bills provided by the occupants.

A dynamic model HTB2 (Lewis and Alexander, 1990) was employed in the thermal simulation, combined with VirVil SketchUp (Jones et al., 2013), an urban scale modelling tool to consider overshadowing impact from the neighbourhood. HTB2 is typical of the more advanced numerical models, using as input data, hourly climate for the location, building materials and construction, spatial attributes, system and occupancy profiles, to calculate the energy required to maintain specified internal thermal conditions. VirVil Sketchup is an extension development of HTB2 in SketchUp for multi-building or big scale modelling. The integrating of the two tools can provide relatively more reliable prediction with shading impact from the surroundings being considered.

\section{Modelling and comparing the neighbourhood system with a separate system for individual}

Modelling of both the neighbourhood system and the separate system approaches has been carried out in the integrated model of Energy Demand, Supply and Storage (EDSS). Like VirVil SketchUp, the EDSS model is also an extension of HTB2, but acts as a post-processer of HTB2 outputs. The model mainly deals with domestic service systems, such as the integration of energy demand of electricity, space heating and hot water, with renewable energy supply from solar PV, solar thermal and Heat pump, assisted by battery storage and thermal storage. And it allows adding or removing system components if required, so is flexible to adjust or reorganize the system. Other thermal components such as the Mechanical Ventilation Heat Recovery (MVHR) system and the Transpired Solar Collector (TSC) are set up in the HTB2 model. The EDSS model developed on an hourly base, can calculate monthly and annual data such as electricity and gas consumption, renewable energy generation, electricity import and export. A schematic of the EDSS model is shown in Figure 1 (see the end of the paper). The Model has been used in previous domestic projects (Jones et al. 2017), proving to be flexible and reliable.

Besides calculating energy consumption, the modelling exercises also estimate the total net $\mathrm{CO}_{2}$ emissions, energy bills and renewable incomes. It used current $\mathrm{CO}_{2}$ emission factors (BRE, 2014) in relation to electricity and gas supply. The total net $\mathrm{CO}_{2}$ emissions is calculated considering both electricity import and export using Equation (1).

$$
m_{\mathrm{CO} 2}=\left(E_{\text {import }}-E_{\text {export }}\right) E F_{\text {electricity }}+E_{\text {gas }} E F_{\text {gas }}
$$

$m_{\mathrm{CO} 2}$ - total net $\mathrm{CO}_{2}$ emission, in $\mathrm{kg} . E_{\text {import }}-$ electricity imported from grid, in $\mathrm{kWh}$. $E_{\text {export }}-$ electricity export to grid, in $\mathrm{kWh} . E_{\text {gas }}-$ gas consumption, in $\mathrm{kWh} . E F_{\text {electricity }}$ $-\mathrm{CO}_{2}$ emission factor for electricity, in $\mathrm{kg} / \mathrm{kWh} . E F_{\text {gas }}-$ $\mathrm{CO}_{2}$ emission factor for gas, in $\mathrm{kg} / \mathrm{kWh}$.

The operating energy costs are estimated based on the latest energy prices. Electricity prices are quoted from the local supplier, including a unit rate of $15.98 \mathrm{p} / \mathrm{kWh}$ and a standing charge of $21.68 \mathrm{p} /$ day. Oil and LPG prices are sourced from energy bills of the residents, such as 4.7 $\mathrm{p} / \mathrm{kwh}$ for oil, $10.08 \mathrm{p} / \mathrm{kWh}$ for LPG. Incomes from solar PV last for 20 years, and can be estimated from UK Government's latest Feed-in Tariffs rates (Ofgem, 2018a) using Equation (2). However, the Feed-in Tariffs will end on $31^{\text {st }}$ Mar.2019, and for domestic scenario, its recommended replacement may only provide financial support for metered electricity export (DBEIS, 2019).

$$
C_{\mathrm{pv}}=E_{\text {generation }} F I T_{\text {generation }}+E_{\text {export }} F I T_{\text {export }}
$$

$C_{\mathrm{pv}}-$ income through the Feed-in Tariffs, in $£ . E_{\text {generation }}-$ electricity generated from solar PV, in $\mathrm{kWh}$. $E_{\text {export }}-$ 
Electricity export to grid, in kWh. FIT $T_{\text {generation }}$ - the Feedin Tariffs rate for PV generation, in $£ / \mathrm{kWh}$. $F I T_{\text {export }}-$ the Feed-in Tariffs rate for electricity export, in $£ / \mathrm{kWh}$.

Income from heat pump is estimated from UK government's Renewable Heat Incentive (RHI) Scheme. For the scenario of separate systems supplying individual dwellings, the domestic RHI rates are used to calculate the related income, while for the scenario of a neighbourhood system supplying all, which is treated as a non-domestic scenario, the nondomestic RHI rates are employed. The RHI income lasts for 7 years for a domestic scenario and 20 years for a non-domestic scenario. The RHI income is calculated according to Equation (3) for a domestic scenario (ofgem, 2017), and Equation (4) for a nondomestic scenario (ofgem, 2018b).

$$
C_{\text {dhp }}=E_{\text {heat }}(1-1 / S P F) R_{\mathrm{d}}
$$

$C_{\text {dhp }}$ - heat pump income of the relevant period through the Renewable Heat Incentive Scheme for domestic scenario, in $£$.

$E_{\text {heat }}$-the annual heat demand figure listed on related Energy Performance Certificate (EPC) or the heat demand limit $(20,000 \mathrm{kWh}$ for air source heat pump, and $30,000 \mathrm{kWh}$ for ground source heat pump), whichever is lower, in $\mathrm{kWh}$; if it is metered for payment for the relevant period, the RHI income is based on actual meter readings, also subjects to the heat demand limit.

$S P F$ - Seasonal Performance Factor of the heat pump.

$R_{\mathrm{d}}$ - Domestic RHI tariff rate, 0.1049 for ASHP, or 0.2046 for GSHP, in $£ / k W h$ (ofgem, 2018c).

$$
C_{\text {ndhp }}=E H O R_{\text {nd }}
$$

$C_{\text {ndhp }}$ - non-domestic heat pump income of the relevant period through the Renewable Heat Incentive Scheme, in $£$.

$E H O$ - Eligible Heat Output generated in the relevant period, in $\mathrm{kWh}$.

$R_{\text {nd }}-$ Non-domestic RHI tariff rate(s), 0.0269 for ASHP, 0.0936 for Tier1 GSHP, 0.0279 for Tier2 GSHP (ofgem,2019), the first 1,314 HP working hours of the year will be payable at the higher Tier1 tariff, while the rest of the year will be payable at the lower Tier 2 tariff.

\section{Payback time and Return on Investment (ROI)}

For domestic retrofit, the payback time measures the amount of time needed to recover the additional investment on energy performance improvements through operating energy cost savings and if applicable the related incomes from government schemes such as the Renewable Heat Incentive, the Feed-In Tariffs or its replacement. The payback time of a package of retrofit strategies can be obtained by solving Equation (5). The additional investment is a sum of initial investments for removing old or useless components, buying and installing new ones, and costs for maintaining the new components at the operating stage. Replacement expenses are included in the maintenance costs for new components with lifespans shorter than the designed system lifespan. The degradation of component performance over time is also considered, such as annual degradation rates of $0.7 \%$ for PV capacity (NREL, 2010) and 2-3\% for lithium battery capacity if managed in good performance (NREL, 2017), for every 10 year, 6-10\% for boilers efficiency and $10-24 \%$ for chillers COP (Waddicor, 2016). A base case scenario is developed for the long term, to provide base case operating energy cost over time as the base case system degrades, for calculating the long-term energy cost saving. And any replacement and maintenance cost of the base case is considered as a return of long-term investment. Besides, a standard UK discount rate of 3.5\% (HM Treasury, 2018) is employed to determine the present value of future cash flows, therefore enable comparison of investments and benefits in the long term. The discount rate here indicates how rapidly the value today of a future real pound decreases by time, and it applies to real values with the anticipated effects of general inflation already removed. It is assumed that inflation will affect all prices equally, in which case the real values of future cash flows equal to the current prices, so the inflation rate isn't applied in the calculation.

$$
\begin{gathered}
C_{\mathrm{in}}+\Sigma_{1}^{t}\left(C_{\mathrm{m} i} /(1+r)^{i-1}\right)-\Sigma_{1}^{t}\left(C_{\mathrm{pv} i} /(1+r)^{i-1}\right)-\Sigma_{1}{ }^{t}\left(C_{\mathrm{hp} i} /(1+r)^{i-1}\right)- \\
\Sigma_{1}^{t}\left(C_{\mathrm{s} i} /(1+r)^{i-1}\right)=0 \\
C_{\mathrm{m} i}=\Sigma_{1}{ }^{n} M_{x}-\Sigma_{1}^{a} M_{b} \\
C_{\mathrm{pv} i}=C_{\mathrm{pv}}(1-\alpha)^{i-1} \\
C_{\mathrm{hp} i}=C_{\mathrm{dhp}}(1-\beta)^{i-1} \text { or } C_{\mathrm{hp} i}=C_{\mathrm{ndhp}}(1-\beta)^{i-1} \\
C_{\mathrm{si}}=\Sigma_{1}{ }^{h}\left(E_{z i} P_{z}\right)-\Sigma_{1}^{m}\left(E_{y i} P_{y}\right)
\end{gathered}
$$

$C_{\text {in }}$ - initial investment for implementing the retrofit strategies; $r$ - discount rate; $C_{\mathrm{m} i}-$ expenses for maintenance of year $i ; t$ - payback time; $C_{\mathrm{pv} i}$-income from Solar PV of year $i$ when $i$ is within the tariff timescale; $C_{\mathrm{hp} i}-\mathrm{RHI}$ income from heat pump of year $i$ when $i$ is within the tariff timescale; $C_{\mathrm{s} i}$ - operating energy cost savings or year $i ; M_{x}, M_{b}$-maintenance fees of new component $x$ and the base case component $b$ respectively; $n, a$ - the total number of retrofit components and base case components respectively; $C_{\mathrm{pv}}, C_{\mathrm{dhp}}, C_{\mathrm{ndhp}}-1^{\text {st }}$ year incomes from PV, heat pump for domestic and nondomestic scenarios respectively, see Equation 2, 3 and 4 for calculation; $\alpha, \beta$ - performance degradation rates for $\mathrm{PV}$ and heat pump respectively; $m$ - the total number of fuels used after optimisation; $E_{y i}$ - post-retrofit energy use of fuel $y$ on year $i$, obtained from the EDSS model with consideration to system performance degradation by time if applicable; $P_{y}$ - price of fuel $y ; y$ - fuel No., ranging from 1 to $m ; h$ - total number of fuels used in a base case scenario; $E_{z i}$ - base case energy use of fuel $z$ on year $i$, obtained from the EDSS model with consideration to system performance degradation of the base case; $P_{z}-$ price of fuel $z ; z$ - fuel No., ranging from 1 to $h$.

Similar to the Payback time, Return on Investment (ROI) measures the amount of return on a particular investment, relative to the investment's cost. A simple formula is presented in Equation (10). Combined with the discount rate above to account for the time scale, a more reliable discounted ROI is developed and presented in Equation (11). A positive value of ROI indicates a good investment, while a negative value indicates a bad one. A graph of ROI vs time can be adopted to identify the payback time 
which is when the ROI value is zero, and the steeper the ROI line the faster the return speed, therefore it can also be used in investments comparison and selection.

$$
R O I=\left(C_{\text {gain }}-C_{\text {cost }}\right) / C_{\text {cost }}
$$

$$
R O I_{i}=\left[\Sigma_{1}^{t}\left(C_{\mathrm{pvi}} /(1+r)^{i-1}\right)+\Sigma_{1}{ }^{t}\left(C_{\mathrm{hp} i} /(1+r)^{i-1}\right)+\Sigma_{1}{ }^{t}\left(C_{\mathrm{s} i} /(1+r)^{i-}\right.\right.
$$$$
\left.{ }^{1}\right)-C_{\mathrm{in}}-\Sigma_{1}^{t}\left(C_{\mathrm{m} i} /(1+r)^{i-1}\right] /\left[C_{\mathrm{in}}+\Sigma_{1}^{t}\left(C_{\mathrm{m} i} /(1+r)^{i-1}\right)\right]
$$

$R O I$ - the Return on Investment rate. $C_{\text {gain }}$ - gain from investment. $C_{\text {cost }}-$ cost of investment. $R O I_{i}-$ the Return on Investment rate on year $i$.

\section{System modelling}

An integrated low carbon system approach normally employs reduced energy loads, passive design, efficient HVAC system, renewable energy supply and energy storage (Jones et al., 2015). A neighbourhood energysharing system (Figure 2) can achieve both optimised system efficiency, renewable energy supply and energy storage, by integrating efficient building service system (mainly heating/cooling) with on-site electricity generation and storage. The capability to supply energy where it is generated and to the whole neighbourhood, can reduce reliability on fossil fuels and grid, maximize energy self-dependency, and reduce energy bills and receive renewable incomes in the case of government programme to promote renewable energy generation. Therefore, it fits the rural houses, which is likely off-gas and in fuel poverty. Compared with a sum of separate energy systems for individual buildings, a neighbourhood system is likely to harvest more renewable energy, such as a bigger PV area to fit standard PV module in the case of a linked roof for multiple properties, and it requires smaller heating/cooling system and energy storage as energy demands and the associated peak times can vary between households, which will greatly reduce initial investment.

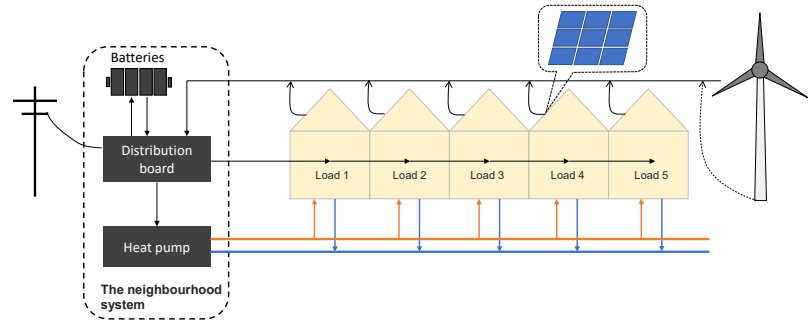

Figure 2: A schematic of the neighbourhood energysharing system.

Based on surveys and monitoring data, simulations were carried out to design the system, together with other low carbon technologies. The neighbourhood system was optimised in terms of energy efficiency, electricity selfsufficiency, environmental performance and cost effectiveness. A comparison between the neighbourhood system and the separate system approach was used to examine the affordability and the replicability at the next step.
Pre-retrofit building performance modelling and validation

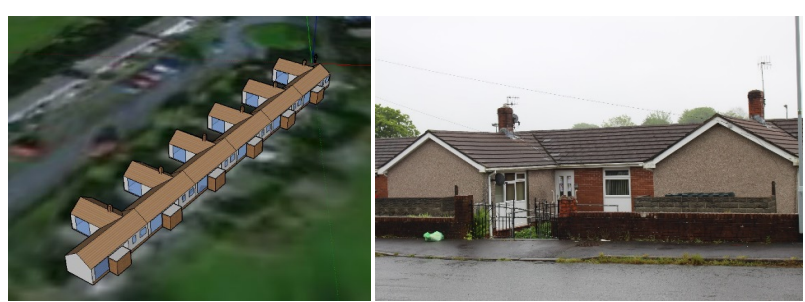

Figure 3: Layout of the bungalows (left: SketchUp model, right: photo of the front, taken by the authors).

The bungalows (from A to F), having an L-shape plan for each, are linked to each other, with the front facing northwest (Figure 3). One of the end terraces $F$ is unoccupied due to structure problem, therefore is only considered for its fabric heat gains or losses to the neighbour in the thermal simulation, but not considered in further analysis. For the rest 5 bungalows, each of them has 2 bedrooms, and is occupied by single or couple. A summary of the pre-retrofit building information is presented in Table 1 (see the end of the paper).

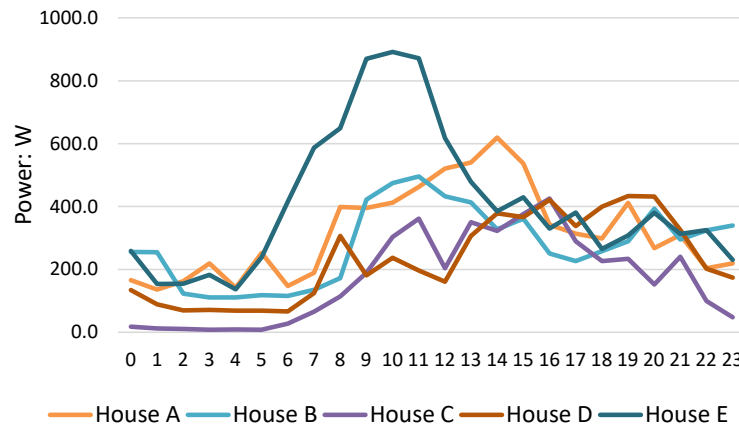

Figure 4: Measured hourly electricity usage profiles of the 5 bungalows on an average day.

Table 2: A comparison of predicted existing heating

\begin{tabular}{|c|c|c|c|}
\hline & House C & House D & House E \\
\hline $\begin{array}{c}\text { Heating } \\
\text { energy } \\
\text { bill/ } \\
\text { estimation }\end{array}$ & $\begin{array}{c}\text { Occupants' } \\
\text { estimation: } \\
£ 720 / \mathrm{yr}\end{array}$ & $\begin{array}{c}\text { 3-month oil } \\
\text { bill } \\
\text { (11Sep2017- } \\
\text { 13Dec2017): } \\
£ 154\end{array}$ & $\begin{array}{c}\text { Monitoring- } \\
\text { based } \\
\text { estimation: } \\
9389 \mathrm{kWh} / \mathrm{yr}\end{array}$ \\
\hline $\begin{array}{l}\text { Predicted } \\
\text { annual } \\
\text { usage/bills }\end{array}$ & $\begin{array}{c}13039 \\
\mathrm{kWh} / \mathrm{yr} \text { or } \\
643 £ / \mathrm{yr}\end{array}$ & $\begin{array}{c}12051 \\
\mathrm{kWh} / \mathrm{yr}, \text { or } \\
595 £ / \mathrm{yr}, \\
£ 149 \text { per } 3- \\
\text { month. }\end{array}$ & $8507 \mathrm{kWh} / \mathrm{yr}$ \\
\hline
\end{tabular}
energy use and bills.

The measured average hourly electricity use profiles of individual houses are presented in Figure 4. They account for electricity usage of appliance and lighting, which are taken as internal gain inputs for the dynamic thermal model. Since they are based on monitoring data from January to April in the heating season, the preparation of the profiles requires identifying, estimating and removing heating electricity usage from the measured total consumption, for houses employing regular electric heating. The using of electric radiators has been identified from survey and tracked from the monitoring data. Figure 4 shows differences among households in terms of electricity usage and peak hour. Air permeability is 9.8 
$\mathrm{m}^{3} / \mathrm{h} / \mathrm{m}^{2}$ according to pressure test done for one of the bungalows, and it is assumed the same for all bungalows. The CIBSE weather data of Test Reference Year for Cardiff has been used to run the simulation. The preretrofit scenario as above is modelled, and its results compared with previous energy bills or estimation present an overall good match, as shown in Table 2. Energy bills of House A and E are either not available or not referable as the timescale of the billed fuel usage is unclear, so are not presented here. Above all, the model is relatively reliable in simulating future scenarios.

\section{Proposed low carbon strategies}

Based on pre-retrofit survey, monitoring and preliminary modelling, a group of low carbon strategies is selected and planned for this case study, including firstly reducing energy demand through fabric insulation, LED lighting, MVHR, then providing efficient and reliable low carbon energy supply through an integrated system of ground source heat pump, solar PV and batteries. A summary of the low carbon technologies is presented in Table 3 (see the last page). For energy supply, two integrated system scenarios are proposed and modelled, such as a neighbourhood system to supply all and separate systems for individual houses. A pre-retrofit scenario and a retrofit scenario with only reduced energy demand (see Table 3 ) strategies are developed to serve as base cases for studying the whole site performance optimisation through different approaches.

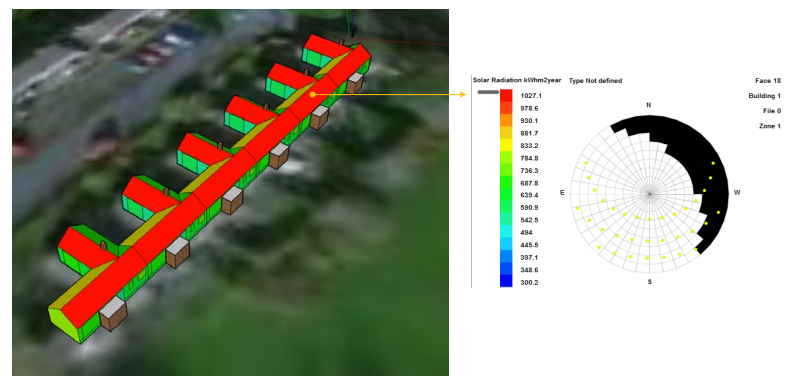

Figure 5: A visualization of solar potentials in VirVil SketchUp.

In Table 3 (at the last page), strategies of reducing energy demand are mainly tailored to comply with Building Regulation (Welsh Government, 2016b) or to provide energy-efficient lighting and ventilation without reducing the current environmental quality, while components of the integrated system are designed to accommodate the reduced energy demand, and to maximize on-site electricity self-sufficiency. A solar analysis is carried out in VirVil Sketchup to identify and locate PV on roof areas with the most solar potential. Figure 5 shows a visualisation of solar potential, with areas in red receiving the most solar radiation, while those in blue receiving the least. The PV area is then calculated considering dimensions of the selected roofs and PV module to achieve maximum electricity production. It shows a neighbourhood system can accommodate $2.8 \mathrm{kWp}$ more PV compared with a sum of separate systems. Since the roofs are quite old and require reroofing, building integrated solar PV instead of bolt on solar PV is used to reduce the total cost of PV and reroofing. For battery,
Tesla battery with a minimum unit capacity of $13.5 \mathrm{kWh}$ has been used in the previous projects and proving to be reliable and cheaper compared with similar products, therefore is proposed for this case study. It should be noted a battery size of $13.5 \mathrm{kWh}$ is more than big to support a separate system, however its price shows better value for money compared with other lithium batteries in the market. Battery of the neighbourhood system is sized according to a performance analysis of electricity selfsufficiency vs battery size see Figure 6 . The stabling zone, that is when electricity self-sufficiency starts changing slowly with battery size, can be identified, and battery size of the minimum unit within zone is selected for the neighbourhood system. Capacity of the ground source heat pump is decided from the predicted peak heating output required to maintain indoor thermal comfort. Prediction from dynamic simulation shows a peak heating output of $6 \mathrm{~kW}$ per separate system, while only $18.5 \mathrm{~kW}$ for the neighbourhood system. Boiler replacements in Table 3 (see the last page) are proposed for the long-term base case scenario in preparation for the ROI calculation.

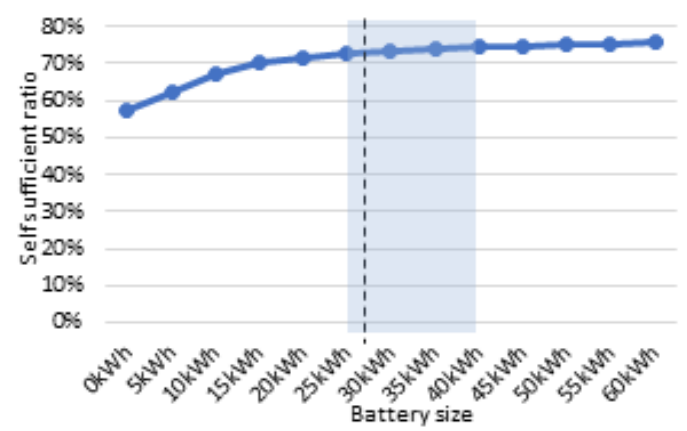

Figure 6: Electricity self-sufficiency vs battery size for the neighbourhood system (by the EDSS model).

\section{Simulation results and discussion}

Annual performance (energy, cost and $\mathrm{CO}_{2}$ emission)

Above all, four scenarios are modelled, such as a preretrofit base case, a retrofit case with strategies of reducing energy demand (see Table 3 ), a post-retrofit case with a neighbourhood energy system, a post-retrofit case with separate energy systems. Simulation results of the four scenarios in relation to energy and environmental performance are compared as below.

A summary of the whole site annual performance in Table 4 (see the end of the paper) indicates: 1) strategies of reducing energy demand can achieve a $30 \%$ decrease for heating fuel, a $13 \%$ decrease for electricity use, a $18 \%$ saving of energy bill, and a $22 \%$ reduction of overall $\mathrm{CO}_{2}$ emission; 2) the neighbourhood system approach can reduce annual $\mathrm{CO}_{2}$ emission by $120.9 \%$ and save annual energy bill by $74.2 \%$; 3) both integrated system approaches, including the neighbourhood one and the separate one, can achieve similar overall electricity selfsufficiency, with more than $70 \%$ of their electricity demand met by onsite electricity production; 4) with a much smaller battery and a relatively bigger PV size, the neighbourhood system scenario imports only $5 \%$ more electricity from grid but export $25 \%$ more electricity to grid, compared with the separate system scenario; 5) 
annual income of the neighbourhood system approach is lower than that of the separate one, due to lower tariffs for nondomestic RHI income applying to the neighbourhood scenario; 6) annual incomes of both integrated system approaches are more than their energy bills respectively; 7) both of the neighbourhood system approach and the separate one can achieve carbon negative for the whole site, with the former contributing to $31 \%$ more carbon reduction compared with the latter.

\section{Long-term economic analysis (ROI and payback time)}

ROIs of the two system approaches are calculated on a base case scenario with reduced energy demand, namely case 2 as above. The existing boilers in the base case scenario are assumed to last for another 10 years, so will be replaced with new ones at year 11, as shown in Table 2. The ROIs of five scenarios are calculated for a designed system lifespan of 30 years, including two PV income scenarios for each system approach, and a scenario of neighbourhood system with bolt on PV under the recommended new PV income tariff. The former is to understand impacts from changing of government financial support, such as from the old Feed in Tariff (before $31^{\text {st }}$ Mar. 2019) to its recommended replacement (after $31^{\text {st }}$ Mar.2019), and the latter is to examine the impact from employing an alternative PV option which is cheaper and more replicable for domestic retrofit.

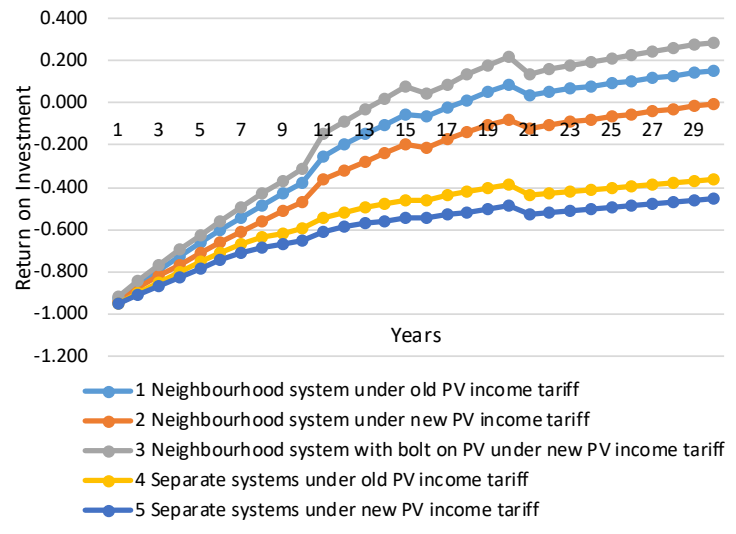

Figure 7: A comparison of ROIs for different scenarios.

A comparison of the ROI profiles in Figure 7 indicates: 1) the neighbourhood system approach can be paid back within the system lifespan under the new PV income tariff; 2) the using of bolt on PV can reduce the payback time to 14 years; 3) the payback time of the neighbourhood system approach under the old PV income tariff is 18 years, much shorter than that under the new tariff; 4) the separate systems approach can't be paid back within 30 years' lifespan under both PV income tariffs; 5) the payback speeds are ranked to be Scenario3 $>$ Scenario1 $>$ Scenario2 $>$ Scenario4 $>$ Scenario5, and year 1-10>year 11-15>=year 16-20>year 21-30.

\section{Conclusion}

This paper has described the modelling and development of a neighbourhood integrated energy system for five offgas rural dwellings in the UK. System design has been discussed and built on site survey, on-going monitoring and validated modelling. The neighbourhood system approach has been compared with the separate systems approach for both short-term and long-term performances. Prediction of annual performance shows the neighbourhood system can achieve similar energy self-sufficiency as the separate system approach with a much smaller investment, and it can achieve carbon negative, and contribute to $31 \%$ more reduction of $\mathrm{CO}_{2}$ emission than the separate one. The ROI analysis indicates the neighbourhood system can be paid back within its lifespan, while the separate systems can't. The payback time of the neighbourhood system can be reduced to 14 years if traditional bolt on PV system is used instead of building integrated PV. The decreasing of government financial support on electricity generation by solar PV has a great impact on the payback time. The outcome of the research has demonstrated the affordability and replicability of the neighbourhood integrated low carbon system, which can decrease fuel poverty, provide secured energy supply, and meet government targets for $\mathrm{CO}_{2}$ reduction.

Another contribution of the paper is to provide a method for feasibility study on new retrofit technology or system, employing energy and environmental performance prediction and long-term economic analysis. The economic analysis should take into account any maintenance and replacement cost, degradation of system performance and discounting of money over time. A limit of the research is to assume inflation will affect all prices equally, without considering differences among real growth rates of individual prices and the average inflation rate in the UK. For example, fuel price of oil or LPG may increase more rapidly than the UK average price as a result of fuel deficiency in the future, which could reduce the payback time of an electricity powered advanced energy supply system in replace of an existing oil or LPG powered system. The consideration of real growth rates of individual prices will be addressed in future research.

\section{Acknowledgement}

The research presented in this paper is part of the SPECIFIC 2 Low Carbon Built Environment project at Cardiff University. SPECIFIC is part-funded by the European Regional Development Fund (ERDF) through the Welsh Government, and also by InnovateUK and the Engineering and Physical Sciences Research Council (EPSRC).

\section{References}

Baeli, M. (2013). Residential retrofit 20 case studies. RIBA pub. London (UK).

BRE (2014). SAP 2012: Government's Standard Assessment Procedure for Energy Rating of Dwellings. BRE. Watford (UK).

CIBSE (2000). TM 23: Testing building for air leakage. CIBSE. London (UK).

Citizens Advice Scotland (CAS) (2016). Living without mains gas. CAS. Edinburgh (UK). 
DBEIS (2019). The future for small-scale low-carbon generation. DBEIS. London (UK).

DBEIS (2017). Annual fuel poverty statistics report, 2017 (2015 data). DBEIS. London (UK).

HM Treasury (2018). The Green Book: Central government guidance on appraisal and evaluation. HM Treasury. London (UK).

Jones, P., Li, X., Perisoglou, E. and J. Patterson (2017). Five energy retrofit houses in South Wales. Energy and Buildings 154, 335-342.

Jones, P., Hou, S. and X. Li (2015). Towards zero carbon design in offices: integrating smart facades, ventilation, and surface heating and cooling. Renewable Energy 73, 69-76.

Jones, P., Lannon, S., Li, X., Bassett, T. and D. Waldron (2013). Intensive building energy simulation at early design stage. Proceedings from the 13th International Conference of the International Building Performance Simulation Association. Chambéry (France), 25-28 August 2013.

Lewis, P.T. and D.K. Alexander (1990). HTB2: A flexible model for dynamic building simulation. Build Environ 25(1), 7-16.

NREL (2010). Outdoor PV Degradation Comparison. Proceedings from the $35^{\text {th }}$ IEEE Photovoltaic Specialists Conference. Hawaii (USA), 20-25 June 2010.
NREL (2017). Life Prediction Model for Grid-connected Li-ion Battery Energy Storage System. Proceedings from the 2017 American Control Conference. Washington (USA), 24-26 May 2017.

Ofgem (2019). Tariffs and payments: Non-Domestic RHI. Ofgem. London (UK).

Ofgem (2018a). Feed-In Tariff (FIT) rates. Ofgem. London (UK).

Ofgem (2018b). Guidance Volume 2: Ongoing obligations and payments. Ofgem. London (UK).

Ofgem (2018c). Tariffs and payments: Domestic RHI. Ofgem. London (UK).

Ofgem (2017). Factsheet: The Domestic RHI-tariffs and payments. Ofgem. London (UK).

Waddicor, D., Fuentes, E., Sisó, L., Salom, J., Favre, B., Jiménez, C. and M. Azar (2016). Climate change and building ageing impact on building energy performance and mitigation measures application: A case study in Turin, northern Italy. Building and Environment 102, 13 -25.

Welsh government (2016a). The production of estimated levels of fuel poverty in Wales: 2012-2016. Welsh government. Cardiff (UK).

Welsh Government (2016b). The Building Regulations 2010 Conservation of fuel and power: approved document L1B existing dwellings (2014 Edition incorporating 2016 amendments). Welsh Government. Cardiff (UK).

\section{Oversized Figures and Tables to follow:}

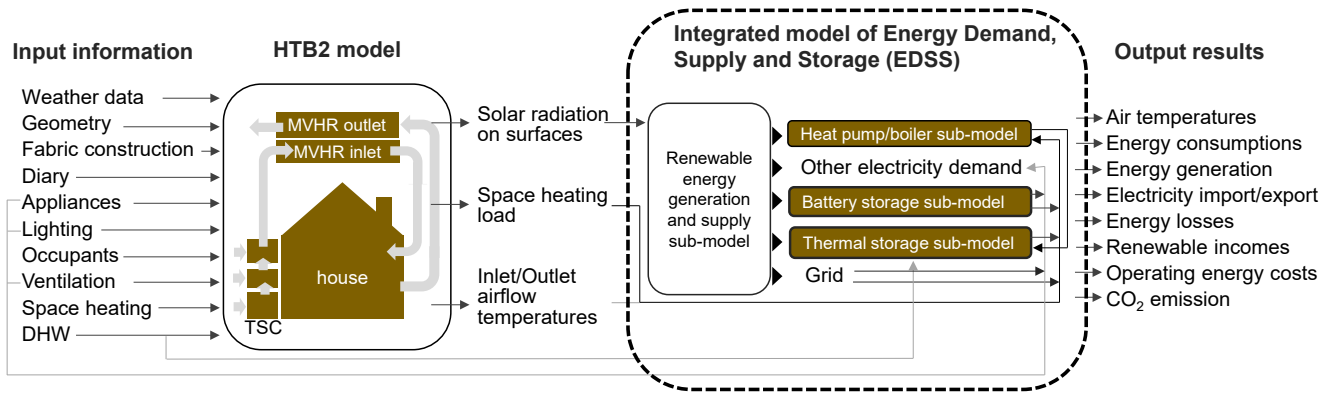

Figure 1: A schematic of the modelling approach.

Table 1: A summary of pre-retrofit building information.

\begin{tabular}{|c|c|c|c|c|c|}
\hline & House A & House B & House C & House D & House E \\
\hline Basic information & \multicolumn{5}{|c|}{ 1970s-built, 2-bedroom bungalow terrace, floor area $61 \mathrm{~m}^{2}$, floor height $2.4 \mathrm{~m}$. } \\
\hline Fabric constructions* & \multicolumn{5}{|c|}{$\begin{array}{l}\text { External wall: filled cavity wall, } \mathrm{U} \text {-value } 0.50 \mathrm{~W} / \mathrm{m}^{2} . \mathrm{K} \text {; } \\
\text { Ground floor: solid without insulation, } \mathrm{U} \text {-value } 1.20 \mathrm{~W} / \mathrm{m}^{2} . \mathrm{K} \text { for end-terrace, } 1.10 \mathrm{~W} / \mathrm{m}^{2} . \mathrm{K} \text { for mid- } \\
\text { terrace. } \\
\text { Roof: pitched roof with loft insulation, } \mathrm{U} \text {-value } 0.13 \mathrm{~W} / \mathrm{m}^{2} . \mathrm{K} \text { for House } \mathrm{A}, 0.36 \mathrm{~W} / \mathrm{m}^{2} . \mathrm{K} \text { for House } \mathrm{B} \text {, } \\
\text { C and } \mathrm{D}, 0.47 \text { for House E. } \\
\text { External window: double glazing, U-value } 2.80 \mathrm{~W} / \mathrm{m}^{2} . \mathrm{K}, \mathrm{G} \text {-value } 0.76 \text {. }\end{array}$} \\
\hline $\begin{array}{l}\text { Heating hours in } \\
\text { winter }\end{array}$ & $\begin{array}{c}7.00-11.00 \\
19.00-21.00\end{array}$ & When want & $7.00-22.00$ & $7.00-21.00$ & $\begin{array}{l}\text { When } \\
\text { want }\end{array}$ \\
\hline Heating setpoint & $20^{\circ} \mathrm{C}$ & $21^{\circ} \mathrm{C}$ & $22^{\circ} \mathrm{C}$ & $22^{\circ} \mathrm{C}$ & - \\
\hline
\end{tabular}




\begin{tabular}{|c|c|c|c|c|c|}
\hline $\begin{array}{l}\text { Boiler brand and } \\
\text { efficiency }\end{array}$ & $\begin{array}{l}\text { LPG back boiler, } \\
\text { BAXI } 553 \text { LPG } \\
\text { (assumed } 80 \% \\
\text { for the worst) }\end{array}$ & $\begin{array}{c}\text { Oil back boiler, } \\
\text { SORRENTO OIL } \\
\text { BOILER 15/18 } \\
(83.6 \%)\end{array}$ & $\begin{array}{c}\text { Oil combi boiler, } \\
\text { WORCESTER } \\
\text { 28CDI } \\
\text { (assumed } 70 \% \\
\text { for the worst) }\end{array}$ & $\begin{array}{l}\text { Oil combi boiler, } \\
\text { WORCESTER } \\
\text { HEATSLAVE } \\
\text { ( } 70 \% \text { for the worst) }\end{array}$ & - \\
\hline $\begin{array}{l}\text { Space heating and } \\
\text { hot water system }\end{array}$ & \multicolumn{5}{|c|}{$\begin{array}{l}\text { For House A-D: instant electric shower, other hot water and space heating are provided by boilers; } \\
\text { For House E: Electric heater for space heating, immersion heating for hot water. }\end{array}$} \\
\hline Cooking fuel & \multicolumn{5}{|c|}{ All use electricity } \\
\hline
\end{tabular}

\begin{tabular}{|c|c|c|c|c|c|}
\hline $\begin{array}{l}\text { Technol } \\
\text { ogies }\end{array}$ & Components & Specifications & $\begin{array}{l}\text { Initial } \\
\text { investment }\end{array}$ & Maintenance cost & Lifespan \\
\hline \multirow{5}{*}{$\begin{array}{l}\text { Reducin } \\
\text { g energy } \\
\text { demand } \\
\text { (per } \\
\text { house) }\end{array}$} & Loft insulation & $\begin{array}{l}\text { Remove existing insulation and install } \\
300 \mathrm{~mm} \text { insulation roll } U \text { value } 0.13 \\
\mathrm{~W} / \mathrm{m} 2 / \mathrm{K}\end{array}$ & $£ 500$ & 0 & $>=80$ years \\
\hline & $\begin{array}{l}\text { External wall } \\
\text { insulation }\end{array}$ & $\begin{array}{l}\text { Graphite EPS board at } 100 \mathrm{~mm} \text {, and panels } \\
\text { under window to be replaced by block } \\
\text { wall and EWI to match, } U \text { value }<=0.25 \\
\mathrm{~W} / \mathrm{m} 2 / \mathrm{K}\end{array}$ & $£ 7000$ & 0 & $>=30$ years \\
\hline & $\begin{array}{l}\text { Window\& door } \\
\text { replacement }\end{array}$ & $\begin{array}{l}\text { High performance double glazing, } \\
\mathrm{U}<=1.5 \mathrm{~W} / \mathrm{m} 2 / \mathrm{K}\end{array}$ & $£ 5000$ & 0 & $20-40$ years \\
\hline & LED lighting & Brightness no less than 800 lumens. & $£ 200$ & 0 & 20 years \\
\hline & $\begin{array}{l}\text { Mechanical } \\
\text { ventilation heat } \\
\text { recovery }\end{array}$ & $\begin{array}{l}\text { Envirovent energiSava 250, } \mathrm{SPF} \\
0.59 \mathrm{~W} / 1 / \mathrm{s}, 91 \% \text { heat efficiency }\end{array}$ & $£ 2500$ & $£ 40 /$ year & 15 years \\
\hline \multirow[t]{4}{*}{$\begin{array}{l}\text { Energy } \\
\text { supply } \\
\text { and } \\
\text { storage } \\
\text { system }\end{array}$} & PV & $\begin{array}{l}\text { Building integrated } \mathrm{PV}, \text { module } \\
\text { efficiency } 19.6 \% \text {, } \\
\text { i) a neighbourhood system: } 32.8 \mathrm{kWp} ; \\
\text { ii) a separate system: } 6.0 \mathrm{kWp} / \mathrm{system} ;\end{array}$ & $\begin{array}{l}£ 2100 \quad \text { per } \\
\text { kWp }\end{array}$ & $\begin{array}{l}£ 20 / \text { yr for cleaning, } \\
\text { inverter replacement } \\
\text { every } 15 \text { years costs } \\
£ 300 \text { per } \mathrm{kWp} P V .\end{array}$ & $25-30$ years \\
\hline & Lithium battery & $\begin{array}{l}\text { Tesla lithium-ion battery, } \\
\text { i) a neighbourhood system: } 27.0 \mathrm{kWh} \text {; } \\
\text { ii) a separate system: } 13.5 \mathrm{kWh} / \mathrm{system} \text {. }\end{array}$ & $\begin{array}{l}£ 6500 \text { for } \\
\text { every } \\
13.5 \mathrm{kWh}\end{array}$ & 0 & $10-20$ years \\
\hline & GSHP & $\begin{array}{l}\text { COP } 4.0, \text { with integrated hot water tank, } \\
\text { i) a neighbourhood system: }>=18.5 \mathrm{~kW} \text {; } \\
\text { ii) a separate system: }>=6 \mathrm{~kW} / \text { system. }\end{array}$ & $\begin{array}{l}£ 25000 \text { for a } \\
25.3 \mathrm{~kW} \\
\text { system; } \\
£ 15000 \text { for a } \\
6 \mathrm{~kW} \text { system. }\end{array}$ & 0 & $\begin{array}{l}25-30 \text { years } \\
\text { for HP, } 50- \\
100 \text { years } \\
\text { for piping }\end{array}$ \\
\hline & $\begin{array}{l}\text { Efficient oil/LPG } \\
\text { boiler }\end{array}$ & $\begin{array}{l}21 \mathrm{~kW} \text { output/boiler, efficiency } 92 \% \text { : } \\
\text { i) system boilers to replace the existing } \\
\text { back boilers; } \\
\text { ii) the existing combi boilers replaced } \\
\text { with high performance ones. }\end{array}$ & $\begin{array}{l}£ 4500 \text { for } \\
\text { system } \\
\text { boiler; } £ 3000 \\
\text { for combi- } \\
\text { boiler. }\end{array}$ & $£ 100 /$ year & 15 years \\
\hline
\end{tabular}

Table 4: A summary of the simulation results.

\begin{tabular}{|c|c|c|c|c|c|c|c|c|}
\hline \multicolumn{2}{|c|}{ For the whole site (5 houses) } & $\begin{array}{c}\text { Gas/oil/LP } \\
\text { G } \\
(\mathrm{kWh} / \mathrm{yr})\end{array}$ & $\begin{array}{c}\text { Electricity } \\
\text { import } \\
(\mathrm{kWh} / \mathrm{yr})\end{array}$ & $\begin{array}{c}\text { Electricity } \\
\text { export } \\
(\mathrm{kWh} / \mathrm{yr})\end{array}$ & $\begin{array}{l}\text { Electricity } \\
\text { self- } \\
\text { sufficiency }\end{array}$ & $\begin{array}{c}\text { Annual } \\
\text { energy } \\
\text { bills } \\
(\mathfrak{f} / \mathbf{y r})\end{array}$ & $\begin{array}{l}\text { Income } \\
\text { s (£/yr) }\end{array}$ & $\begin{array}{c}\text { Total } \mathrm{CO}_{2} \\
\text { emission } \\
(\mathrm{kg} / \mathrm{yr})\end{array}$ \\
\hline \multicolumn{2}{|c|}{ Pre-retrofit } & 40094 & 20866 & 0 & - & 5909 & - & 22465 \\
\hline \multicolumn{2}{|c|}{ Reducing energy demand } & 28205 & 18071 & 0 & - & 4831 & - & 17549 \\
\hline \multirow{2}{*}{$\begin{array}{c}\text { Low } \\
\text { carbon } \\
\text { energy } \\
\text { supply } \\
\text { system }\end{array}$} & $\begin{array}{l}\text { A neighbourhood } \\
\text { integrated system }\end{array}$ & 0 & 5306 & 12374 & $73.2 \%$ & 1244 & 2995 & -3668 \\
\hline & $\begin{array}{c}\text { Separate } \\
\text { integrated systems }\end{array}$ & 0 & 5075 & 9930 & $74.3 \%$ & 1207 & 4217 & -2520 \\
\hline
\end{tabular}

